\title{
GEOCHEMICAL CHARACTERIZATION OF SOME ESTONIAN METABENTONITES
}

\author{
Enli KIIPLI and Toivo KALLASTE
}

\author{
Geoloogia Instituut (Institute of Geology), Estonia psî. 7, EE-0001 Tallinn, Eesti \\ (Estonia)
}

Presented by Enn Pirrus

Received 27 June 1995, accepted 18 December 1995

\begin{abstract}
The X-ray fluorescence analysis of chemical elements, supported by X-ray diffractometric mineralogy, shows a change in the composition of main and trace elements in the Palaeozoic altered tephra layers, metabentonites, compared to the unaltered potential source volcanics. As the correlation analysis gives several associations of elements, including that of immobile elements, a source volcanic composition based on $\mathrm{Nb} / \mathrm{Y}$ and $\mathrm{Zr} / \mathrm{TiO}_{2}$ ratios can be found for 36 Estonian metabentonite samples. Most of these metabentonites are of rhyodacite/dacite and trachyandesite origin, the smaller part derives from rhyolitic and trachytic source magma.
\end{abstract}

Key words: Estonia, metabentonite, chemical composition, Lower Palaeozoic.

\section{INTRODUCTION}

In Estonia Palaeozoic volcanic tephra layers, metabentonites (MBs), have been investigated by Jürgenson (Юргенсон, 1958, 1964, 1988), Utsal and Jürgenson (Утсал \& Юргенсон, 1971), Vingisaar (Вингисаар, 1972), and Vingisaar and Murnikova (Вингисаap \& Мурникова, 1973) since 1950s. The main characteristic features of Palaeozoic MBs or K-bentonites, as they are called in other countries, are their illite-smectite mixedlayer composition, the presence and secondary origin of potassium, due to its absorption from seawater (Юргенсон, 1958) or to hydrothermal processes during illitization (Brusewitz, 1986; Hay et al., 1988), and the absence of original unaltered vitric material. However, there are numerous exceptions concerning mainly the mineralogical composition: the layers consisting of kaolinite (Лапинскас, 1965; Snäll, 1978) or K-feldspar (Hay et al., 1988) or their mixtures with illite-smectite are found. The aim of geochemical investigations is to detect the original magma composition, locality, and tectonic setting of the source volcanoes and to find out correlations between layers over great distances (Huff \& Kolata, 1989; Bergström et al., 1992; Huff et al., 1993). The correlation of the Middle Ordovician MBs, especially concerning "Big Bentonite" ("BB") or Kinnekulle K-bentonite, is based upon stratigraphically well determined palaeontological data as well as on chemical fingerprinting (Bergström et al., 1995) .

This paper attempts to present the chemical composition of $\mathrm{MBs}$, the possibilities of the use of trace elements in determining the original magma composition, and point out the changes that $\mathrm{MBs}$ have gone through during diagenesis. 
(elements, ppm; oxides, \%)

\begin{tabular}{|c|c|c|c|c|c|c|c|c|c|c|c|c|c|c|c|c|c|c|c|c|c|c|}
\hline No. & Sample & Stage & $\mathrm{Nb}$ & $\mathrm{Zr}$ & $\mathrm{Y}$ & $\mathrm{Sr}$ & $\mathrm{Rb}$ & Th & $\mathrm{Zn}$ & $\mathrm{Ni}$ & $\mathrm{Mn}$ & $\mathrm{U}$ & $\mathrm{Fe}_{2} \mathrm{O}_{3}$ & $\mathrm{TiO}_{2}$ & $\mathrm{CaO}$ & $\mathrm{K}_{2} \mathrm{O}$ & $\mathrm{Al}_{2} \mathrm{O}_{3}$ & $\mathrm{MgO}$ & $\mathrm{Nb} / \mathrm{Y}$ & $\mathrm{Zr} / \mathrm{TiO}_{2}$ & \begin{tabular}{|c} 
XRD \\
mineralogy \\
\end{tabular} & $\begin{array}{l}\text { Source magma composition according } \\
\text { to Winchester \& Floyd (1977) }\end{array}$ \\
\hline 1 & ki38.16 & $\mathrm{H}$ & 6 & 198 & 6 & 77 & 56 & 18 & 30 & 10 & 90 & $<10$ & 1.48 & 0.251 & 0.4 & 15.3 & 19.8 & 0.6 & 1.07 & 0.08 & K-fsp & Rhyodacite-trachyandesite-trachyte \\
\hline 2 & pa & $\mathrm{D}_{1} / \mathrm{D}_{11}$ & 15 & 191 & 14 & 18 & 66 & 20 & 50 & 20 & 100 & $<10$ & 4.22 & 0.323 & 0.4 & 13.9 & 19.0 & 1.0 & 1.06 & 0.06 & & Trachyandesite \\
\hline 3 & ki17.2 & $\mathrm{H}$ & 8 & 234 & 18 & 274 & 63 & 10 & 10 & 40 & 50 & $<10$ & 1.91 & 0.635 & 1.1 & 13.6 & 17.6 & 0.9 & 0.45 & 0.04 & K-isp & Rhyodacite/dacite \\
\hline 4 & jo & $D_{11}$ & 12 & 462 & 34 & 17 & 68 & 10 & 10 & 20 & 40 & $<10$ & 2.19 & 0.422 & 0.8 & 13.5 & 19.9 & 1.4 & 0.34 & 0.11 & & Rhyodacite/dacite-rhyolite \\
\hline 5 & vi151.8 & $\mathrm{H}$ & 12 & 287 & 22 & 301 & 75 & 30 & 20 & 60 & 110 & 10 & 1.61 & 0.785 & 1.8 & 13.3 & 20.2 & 1.0 & 0.57 & 0.04 & & Rhyodacite/dacite-trachyandesite \\
\hline 6 & ki15.5 & $\mathrm{H}$ & 28 & 478 & 37 & 43 & 69 & 10 & 30 & 20 & 50 & 10 & 1.65 & 0.463 & 1.6 & 12.9 & 20.1 & 2.4 & 0.74 & 0.10 & K-fsp \& i/s & Rhyolite \\
\hline 7 & ki1 17.85 & $\mathrm{H}$ & 28 & 338 & 16 & 40 & 80 & 35 & 0 & 20 & 40 & $<10$ & 1.57 & 0.298 & 0.4 & 12.6 & 21.8 & 2.0 & 1.73 & 0.11 & K-fsp \& i/s & Trachyte \\
\hline 8 & vil 145.7 & $\mathrm{H}$ & 15 & 356 & 24 & 162 & 64 & 16 & 30 & 80 & 60 & 10 & 1.57 & 0.671 & 2.4 & 12.2 & 19.7 & 1.3 & 0.62 & 0.05 & & Rhyodacite/dacite \\
\hline 9 & vi185.1 & $\mathrm{H}$ & 8 & 224 & 6 & 103 & 86 & 31 & 20 & 20 & 140 & $<10$ & 2.48 & 0.401 & 0.5 & 12.1 & 20.9 & 2.5 & 1.33 & 0.06 & & Rhyodacite-trachyandesite-trachyte \\
\hline 10 & vil 52.1 & $\mathrm{H}$ & 15 & 337 & 27 & 375 & 65 & 34 & 40 & 60 & 40 & 30 & 2.07 & 1.177 & 1.5 & 11.9 & 19.8 & 1.6 & 0.57 & 0.03 & & Rhyodacite/dacite-trachyandesite \\
\hline 11 & vil 148.8 & $\mathrm{H}$ & 12 & 276 & 44 & 361 & 88 & 29 & 30 & 150 & 150 & 30 & 3.11 & 1.089 & 2.6 & 11.6 & 19.2 & 1.9 & 0.27 & 0.03 & & Andesite-rhyodacite/dacite \\
\hline 12 & ki15.8 & $\mathrm{H}$ & 29 & 687 & 44 & 71 & 78 & 27 & 30 & 10 & 30 & $<10$ & 1.98 & 0.657 & 0.7 & 10.7 & 22.1 & 3.0 & 0.65 & 0.10 & $K-f s p \& i / s$ & Rhyolite \\
\hline 13 & vil 49.4 & $\mathrm{H}$ & 32 & 350 & 4 & 66 & 90 & 42 & 10 & 20 & 40 & $<10$ & 1.94 & 0.331 & 0.5 & 10.4 & 22.6 & 2.6 & 8.89 & 0.11 & & Trachyte \\
\hline 14 & oh191.8 & $\mathrm{J}_{2}$ & 15 & 300 & 32 & 149 & 73 & 15 & 10 & 20 & 70 & $<10$ & 1.80 & 0.878 & 2.2 & 9.8 & 21.4 & 2.7 & 0.46 & 0.03 & $K-f s p \& i / s$ & Rhyodacite/dacite \\
\hline 15 & oh4 411.8 & $\mathrm{G}_{1-2}$ & 25 & 542 & 60 & 79 & 116 & 17 & 20 & 40 & 40 & 10 & 3.30 & 0.847 & 0.7 & 8.9 & 20.1 & 3.7 & 0.42 & 0.06 & $\mathrm{~K}$-fsp \& i/s & Rhyodacite/dacite \\
\hline 16 & oh154.25 & $\mathrm{K}_{1}$ & 29 & 301 & 14 & 78 & 95 & 28 & 30 & 10 & 80 & 10 & 1.51 & 0.391 & 0.7 & 8.6 & 22.0 & 4.5 & 2.15 & 0.08 & K-fsp \& i/s & Trachyte \\
\hline 17 & vi121.03 & $\mathrm{H}$ & 19 & 452 & 17 & 177 & 68 & 31 & 0 & 100 & 20 & 30 & 1.86 & 0.570 & 0.6 & 8.6 & 22.6 & 2.5 & 1.09 & 0.08 & & Trachyandesite \\
\hline 18 & mu105.88 & $\mathrm{H}$ & 12 & 340 & 42 & 81 & 139 & 24 & 40 & 40 & 150 & $<10$ & 4.66 & 0.475 & 0.8 & 8.5 & 20.9 & 2.6 & 0.28 & 0.07 & & Rhyodacite/dacite \\
\hline 19 & oh465.93 & $\mathrm{D}_{11}$ & 7 & 239 & 17 & 53 & 111 & 29 & 50 & 30 & 80 & 10 & 2.86 & 0.522 & 0.6 & 8.3 & 20.5 & 4.7 & 0.40 & 0.05 & K-fsp \& i/s & Rhyodacite/dacite \\
\hline 20 & kp95.15 & $\mathrm{H}$ & 28 & 295 & 14 & 99 & 91 & 45 & 40 & 30 & 50 & 20 & 3.40 & 0.525 & 0.8 & 8.3 & 20.8 & 3.0 & 2.03 & 0.06 & & Trachyandesite--trachyte \\
\hline 21 & oh201.46 & $\mathrm{J}_{2}$ & 17 & 342 & 30 & 108 & 94 & 11 & 40 & 20 & 150 & 30 & 4.22 & 0.782 & 2.9 & 8.2 & 20.4 & 3.6 & 0.55 & 0.04 & K-fsp \& i/s & Rhyodacite/dacite \\
\hline 22 & oh154.4 & $\mathrm{K}_{1}$ & 25 & 267 & 12 & 67 & 81 & 29 & 10 & 10 & 70 & $<10$ & 1.29 & 0.380 & 0.6 & 8.1 & 19.2 & 3.8 & 2.03 & 0.07 & K-fsp \& i/s & Trachy andesite-trachyte \\
\hline 23 & vil 56.8 & $\mathrm{H}$ & 17 & 353 & 56 & 174 & 61 & 26 & 10 & 40 & 40 & 10 & 2.76 & 0.853 & 1.4 & 7.9 & 23.0 & 2.3 & 0.30 & 0.04 & & Rhyodacite/dacite \\
\hline 24 & oh375.06 & $\mathrm{G}_{3}$ & 17 & 322 & 31 & 111 & 101 & 20 & 30 & 40 & 110 & 10 & 4.86 & 1.239 & 2.9 & 7.8 & 17.8 & 2.4 & 0.55 & 0.03 & $K-f s p \& i / s$ & Andesite-rhyodacite/dacite \\
\hline 25 & vi148.0 & $\mathrm{H}$ & 38 & 785 & 39 & 118 & 95 & 47 & 60 & 40 & 120 & 40 & 3.74 & 0.934 & 2.1 & 7.7 & 20.7 & 3.1 & 0.98 & 0.08 & & Trachyandesite \\
\hline 26 & oh 466.3 & $\mathrm{D}_{\mathrm{I}} / \mathrm{D}_{\mathrm{II}}$ & 11 & 214 & 19 & 63 & 119 & 21 & 20 & 20 & 50 & 10 & 3.25 & 0.429 & 0.9 & 7.5 & 19.3 & 4.2 & 0.57 & 0.05 & & Rhyodacite/dacite-trachyandesite \\
\hline 27 & vil 47.5 & $\mathrm{H}$ & 36 & 850 & 36 & 128 & 80 & 35 & 20 & 120 & 50 & $<10$ & 3.41 & 0.910 & 0.9 & 7.3 & 22.2 & 3.0 & 1.00 & 0.09 & & Trachyandesite \\
\hline 28 & vil 173.1 & $\mathrm{H}$ & 34 & 477 & 13 & 105 & 99 & 38 & 20 & 30 & 40 & $<10$ & 5.47 & 0.629 & 0.6 & 7.3 & 21.2 & 3.0 & 2.66 & 0.08 & & Trachyte \\
\hline 29 & oh233.4 & $\mathrm{J}_{2}$ & 40 & 845 & 66 & 90 & 83 & 91 & 20 & 30 & 100 & 50 & 2.63 & 1.526 & 1.1 & 7.1 & 26.2 & 2.6 & 0.61 & 0.06 & $i / s \& K-f s p$ & Rhyodacite/dacite \\
\hline 30 & oh307.6 & $\mathrm{J}_{2}$ & 22 & 210 & 13 & 72 & 86 & 30 & 10 & 10 & 60 & 10 & 1.45 & 0.353 & 0.8 & 6.6 & 18.5 & 4.1 & 1.65 & 0.06 & & Trachyandesite-trachyte \\
\hline 31 & ka415.1 & $\mathrm{D}_{\mathrm{I}} / \mathrm{D}_{\mathrm{II}}$ & 13 & 183 & 19 & 76 & 132 & 15 & 30 & 20 & 70 & $<10$ & 3.69 & 0.292 & 0.8 & 6.3 & 17.2 & 3.5 & 0.66 & 0.06 & & Rhyodacite/dacite-trachyandesite \\
\hline 32 & oh298.5 & $\mathrm{J}_{2}$ & 19 & 245 & 22 & 102 & 102 & 38 & 110 & 40 & 160 & 10 & 4.25 & 0.587 & 3.8 & 5.6 & 18.5 & 3.4 & 0.86 & 0.04 & terrigenous? & Trachyandesite \\
\hline 33 & vi115.02 & $\mathrm{H}$ & 30 & 694 & 28 & 165 & 54 & 37 & 0 & 40 & 50 & $<10$ & 1.85 & 0.970 & 1.2 & 5.3 & 25.7 & 2.5 & 1.05 & 0.07 & & Trachyandesite \\
\hline 34 & oh369.12 & $\mathrm{H}$ & 48 & 639 & 60 & 94 & 52 & 47 & 50 & 10 & 30 & 40 & 1.72 & 0.716 & 0.5 & 4.2 & 31.5 & 1.9 & 0.80 & 0.09 & kaolinite & Rhyolite-trachyandesite \\
\hline & ru488.5 & $\mathrm{H}$ & 22 & 400 & 27 & 67 & 65 & 65 & 10 & 20 & 40 & $<10$ & 4.14 & 0.487 & 0.6 & 4.0 & 25.4 & 2.4 & 0.81 & 0.08 & & Rhyolite-trachyandesite \\
\hline \multirow[t]{2}{*}{$\begin{array}{l}35 \\
36\end{array}$} & oh369.9 & $\mathrm{H}$ & 48 & 614 & 64 & 87 & 41 & 46 & 0 & 20 & 30 & 30 & 1.31 & 0.664 & 0.5 & 3.6 & 25.6 & 1.4 & 0.74 & 0.09 & kaolinite & Rhyolite \\
\hline & & STD & 1 & 2 & 2 & 2 & 3 & 2 & 19 & 5 & 36 & 6 & 0.38 & 0.014 & 0.027 & 0.057 & 0.8 & 0.1 & & & & \\
\hline
\end{tabular}

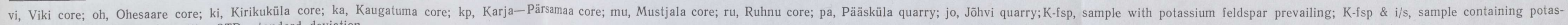
sium feldspar and illite-smectite; STD, standard deviation. 



\section{ANALYTICAL METHODS}

Thirty-six whole-rock samples of Estonian MBs were analysed ori trace elements $\mathrm{Nb}, \mathrm{Zr}, \mathrm{Y}, \mathrm{Sr}, \mathrm{Rb}, \mathrm{Th}, \mathrm{Mn}, \mathrm{Ti}, \mathrm{Zn}, \mathrm{Ni}$, and main components $\mathrm{K} 2 \mathrm{O}, \mathrm{CaO}, \mathrm{Fe}_{2} \mathrm{O}_{3}, \mathrm{Al}_{2} \mathrm{O}_{3}, \mathrm{MgO}$ (Table). As, Cl, S, and $\mathrm{Pb}$ were determined, but not included in the Table because their concentrations were under detection limit.

The criterion for the selection of elements was their sufficient content for X-ray fluorescence (XRF) analyses carried out using the apparatus available at the Petrological Laboratory of the Institute of Geology of the Estonian Academy of Sciences (VRA-30, Ag-anode, $30 \mathrm{~mA}$ and $50 \mathrm{kV}$ ). The approximate impulses in seconds per one percent content of an element are: $\mathrm{Nb}, \mathrm{Zr}, \mathrm{Y}-110000, \mathrm{Sr}-90000, \mathrm{Rb}-80000, \mathrm{Zn}-29000$, $\mathrm{Th}-19000, \mathrm{~Pb}-15000, \mathrm{Ni}-6000, \mathrm{Mn}-5200, \mathrm{Ti}, \mathrm{Fe}-1200, \mathrm{Ca}-$ $750, \mathrm{~K}-500$. The element $\mathrm{U}$ was measured, but because of its low content (U has 2500 impulse/sec per $1 \%$, but its content is less than $10 \mathrm{ppm}$ ) the values obtained are of qualitative and not quantitative importance. The analytical variation was calculated based on the concentration of $M B$ elements after six measurements of the reference sample and two standard deviations were taken to achieve the $90 \%$ confidence limits.

The mineralogical composition of the $M B$ samples was investigated qualitatively by the X-ray diffraction method on the HZG-4 diffractometer using Fe-filtered Co radiation. The rock powder was mixed with several drops of ethyl alcohol and spread on a glass slide. Counting data were collected in the range of $20-44$ degrees (2-theta).

\section{SAMPLES}

Of the total number of samples analysed, thirty-two belong to the Silurian: Ludlow (Rootsiküla Stage), Upper Wenlock (Jaagarahu Stage), and Llandovery (Adavere, Raikküla, and Juuru stages); four samples come from the Ordovician Caradoc: three from the boundary of the Keila and Jõhvi stages and one from the Keila Stage. Figure 1 shows the sampling localities and gives the sections of three cores and positions of investigated samples. Thirteen MB samples were taken from the Ohesaare drillcore, 12 from the Viki core, 5 from the Kirikuküla core; Jõhvi quarry, Pääsküla quarry, Kaugatuma, Ruhnu, Mustjala, and Karja-Pärsamaa drillcores are each represented by one sample. The investigated samples characterize only a small part of $M B$ layers; for example in the Ohesaare core there are recorded 20 layers in the Jaagarahu Stage, 5 layers in the Jaani Stage, and 20 layers in the Adavere Stage (E. Jürgenson, pers. comm.).

The Silurian deposits of the Ohesaare core represent fairly deep-water clay and marl facies, those of the Kirikuküla core belong to relatively shallow-water marl and nodular limestone facies, whereas the sediments of the Viki core lie between them (Кальо, 1970). The MBs from the Ordovician deposits belong facially to open shelf deposits of medium water depth (Мянниль, 1966).

\section{XRD MINERALOGY}

Five MB samples were investigated from the Kirikuküla core and 12 samples from the Ohesaare core. These consist of three main minerals illite (mixed-layer illite-smectite), K-feldspar, and kaolinite - the ratio 


\section{Ohesaare}

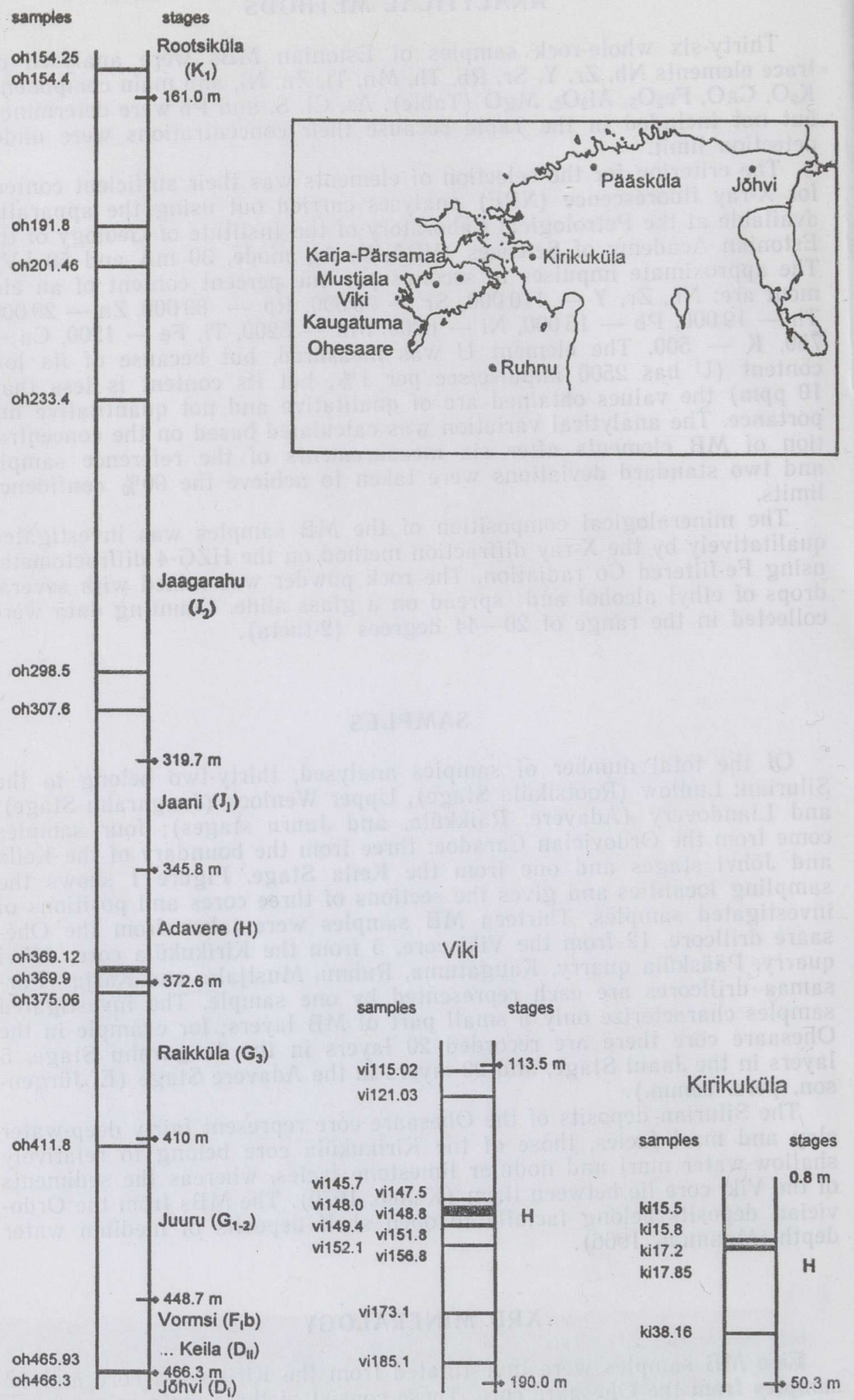


Fig. 1. Location of boreholes and quarries (filled circles) from which MB samples were investigated; positions of $\mathrm{MB}$ layers in the Ohesaare, Viki, and Kirikuküla sections. $M B$ samples investigated in the present paper are supplied with names. Stratigraphy compiled by Tarmo Kiipli according to Jeppsson \& Männik, 1993; Jeppsson et al., 1994; Nestor, 1994; Perens, 1995; Kaljo et al., 1996, plus unpublished data of $\delta^{13} \mathrm{C}$.

of which is greatly varying in different samples up to the occurrence of nearly monomineral samples (Fig. 2). Illite was identified by 020 reflection. This method does not permit us to differentiate between illite and mixed-layer illite-smectite. Determination of the K-feldspar type in several Estonian MB samples has revealed the existence of low sanidine.

Among the investigated MB samples, the most frequent are illite (illite-smectite) and K-feldspar-containing samples without kaolinite. According to the X-ray diffractogram, one of the Kirikuküla core samples (ki38.16) consists totally of K-feldspar. Kaolinite was not detected in the Kirikuküla core.

In the Ohesaare core there are two layers consisting mainly of kaolinite (samples oh369.9 and oh369.12). These samples, as well as all samples of the Kirikuküla core with a predominantly K-feldspar composition, come from the Adavere Stage. This may show lateral variation of the mineralogical composition inside one stratigraphical unit depending on different facial conditions of diagenesis, although exact correlation of layers is impossible because of the absence of the criteria for precise identification of coeval layers. One Ohesaare sample (oh298.5) is probably not MB but clay with a low carbonate content according to the X-ray diffractogram.

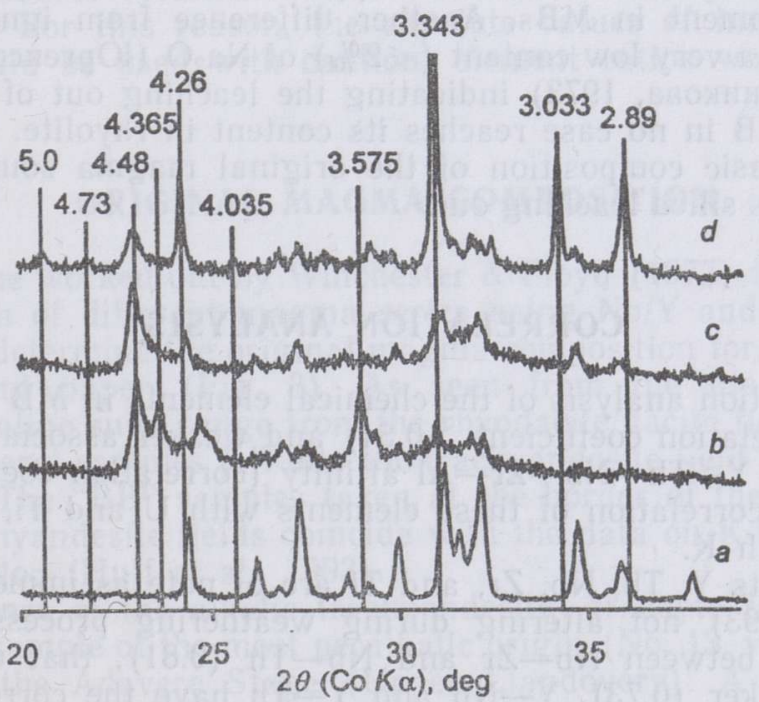

Fig. 2. X-ray diffractograms of different $M B$ samples. Selected $d$-values in $\AA$ are given on top. $a$ (ki38.16), reflections of only K-feldspar were recorded; $b$ (oh369.93), sample dominated by kaolinite, possibly with a certain amount of illite and some K-feldspar; c (oh307.60), illite (illite-smectite) with K-feldspar admixture, one of the greatest illitefeldspar ratios among samples of this type; $d$ (oh298.5), sample possibly dominated by terrigenous material; reflections of quartz (4.255 and $3.343 \AA$ ), carbonates (3.033 and $2.89 \AA)$, chlorite $(4.73 \AA)$, plagioclase $(4.035 \AA)$ are not characteristic of $M B$ samples. 
Among other minerals quartz, representing the terrigenous component, is of note. Judging from the intensities of quartz reflections, the terrigenous component is of little importance or is absent in most of the MB samples.

Pyrite, calcite, and dolomite were determined in some samples as random additional minerals. Biotite is very common and visually detected in most of the samples. Zircon is a prevailing heavy mineral (20$60 \%$ from the $10 \%$ content of heavy minerals in sand-silt fraction which makes up to $10 \%$ of the sample) (Юрreнсон, 1988).

\section{CHEMICAL COMPOSITION}

The chemical data presented in the Table are arranged according to the $\mathrm{K}_{2} \mathrm{O}$ content in $\mathrm{MB}$ samples. As the mineralogical investigations have proved, the $\mathrm{K}_{2} \mathrm{O}$ content depends proportionally upon the $\mathrm{K}$-feldspar amount. In the samples with the $\mathrm{K}_{2} \mathrm{O}$ content over $10 \%$, K-feldspar is supposed to dominate. The samples with the $\mathrm{K}_{2} \mathrm{O}$ content of $6-10 \%$ are considered to have the composition with illite-smectite prevailing. The samples with the $\mathrm{K}_{2} \mathrm{O}$ content less than $6 \%$ belong to the group containing kaolinite. Great variation of the $\mathrm{K}$ content is probably connected with $\mathrm{K}$ incorporation into the source volcanic material or its leaching out during diagenesis.

The content of $\mathrm{Al}_{2} \mathrm{O}_{3}$ varies from 18 to $32 \%$. The comparison of $\mathrm{Al}_{2} \mathrm{O}_{3}$ in $\mathrm{MB}$ with that of igneous rocks shows higher values for $M B$. The maximum $\mathrm{Al}_{2} \mathrm{O}_{3}$ content occurs in kaolinite samples exceeding that of rhyolite by about two and a half times. Theoretically, there is no possibility for aluminium to dissolve and move away in seawater as it is insoluble in pH 4-10 (Войткевич \& Закруткин, 1976); so there must occur residual enrichment in MBs. Another difference from igneous rocks is the absence or a very low content $(<2 \%)$ of $\mathrm{Na}_{2} \mathrm{O}$ (Юргенсон, 1964; Вингисаар \& Мурникова, 1973) indicating the leaching out of sodium.

Silica in MB in no case reaches its content in rhyolite. This does not refer to the basic composition of the original magma source, but more probably shows silica leaching out.

\section{CORRELATION ANALYSIS}

The correlation analysis of the chemical elements in $M B$ yields several stronger (correlation coefficient $>0.54$ ) and weaker associations:

(1) Strong $\mathrm{Y}-\mathrm{Th}-\mathrm{Nb}-\mathrm{Zr}-\mathrm{Al}$ affinity (correlation coefficient $0.62-$ 0.81 ), weaker correlation of these elements with $\mathrm{U}$ and $\mathrm{Ti}$, and negative correlation with $\mathrm{K}$.

The elements $\mathrm{Y}, \mathrm{Th}, \mathrm{Nb}, \mathrm{Zr}$, and $\mathrm{Ti}$ are of note as immobile elements (Rollinson, 1993) not altering during weathering processes. The best correlation is between $\mathrm{Nb}-\mathrm{Zr}$ and $\mathrm{Nb}-\mathrm{Th}(0.81)$, that of $\mathrm{Zr}-\mathrm{Y}$ and $\mathrm{Zr}-\mathrm{Th}$ is weaker $(0.73), \mathrm{Y}-\mathrm{Nb}$ and $\mathrm{Y}-\mathrm{Th}$ have the correlation coefficients 0.67 and 0.63 , respectively. Since these elements form a group with good positive correlation, they supposedly behave similarly in enrichment and depletion processes during diagenesis.

The positive aluminium and negative potassium correlation for the whole MB sample set can be explained by the greater content of $\mathrm{Y}$, Th, $\mathrm{Nb}$, and $\mathrm{Zr}$ in kaolinitic samples that are poor in potassium and rich in aluminium.

(2) Strong $\mathrm{Sr}-\mathrm{Ni}$ correlation (correlation coefficient 0.68 ) and their weaker correlation with $\mathrm{Ti}$. This is probably connected with the basic 
component of volcanic ash. Ni contents of $80-150 \mathrm{ppm}$ are recorded in the Adavere Stage in four samples from the Viki core. Greater values of $\mathrm{Sr}$ are also detected in the Viki core, where the layers with higher $\mathrm{Sr}$ values alternate with those having lower values, and in one sample from the Kirikuküla core. In other cores investigated the analogous layers are either absent or not sampled in the present study.

(3) The $\mathrm{Rb}-\mathrm{Mg}-\mathrm{Fe}$ association probably occurs in biotite.

(4) The $\mathrm{Mn}-\mathrm{Ca}$ association characterizes calcite and dolomite, where substitution of $\mathrm{Mn}$ for $\mathrm{Ca}$ takes place.

(5) The weak $\mathrm{Fe}-\mathrm{Mn}$ association characterizes substitution of $\mathrm{Mn}$ for $\mathrm{Fe}$ in biotite or in some other additional minerals with the exception of pyrite.

(6) Weak positive correlation of $\mathrm{Zn}$ with $\mathrm{Mn}, \mathrm{Fe}, \mathrm{Ca}$, and $\mathrm{Rb}$ seems to have an occasional character.

\section{USE OF IMMOBILE ELEMENT DATA}

Immobile elements $\mathrm{Nb}, \mathrm{Y}, \mathrm{Zr}$, and $\mathrm{Ti}$ and their ratios are used for the discrimination between different magma series (Winchester \& Floyd, 1977) and tectonic settings (Pearce et al., 1984, cited in Huff et al., 1993).

The analysis of the kaolinitic MB samples revealed nearly three times higher contents of immobile trace elements compared to the mean rhyolite content after Winchester and Floyd (1977): Nb $16 \mathrm{ppm}$ vs $49 \mathrm{ppm}, \mathrm{Zr}$ $219 \mathrm{ppm}$ vs $639 \mathrm{ppm}, \mathrm{Y} 26 \mathrm{ppm}$ vs $64 \mathrm{ppm}, \mathrm{TiO}_{2} 2000 \mathrm{ppm}$ vs $7100 \mathrm{ppm}$. Supposing the origination of these elements from the rhyolitic magma, there occurred residual enrichment with them in kaolinites. This suggestion supports the conclusion derived from aluminium enrichment in the same samples. Evidently, there have been great changes in the composition of the source volcanic material, connected mainly with the $\mathrm{Si}$ and $\mathrm{K}$ movement. For this reason, the absolute values of immobile element contents should be used with caution; element ratios would be applied instead.

\section{ORIGINAL MAGMA COMPOSITION}

The scheme worked out by Winchester \& Floyd (1977) for geochemical discrimination of different magma series using $\mathrm{Nb} / \mathrm{Y}$ and $\mathrm{Zr} / \mathrm{TiO}_{2}$ ratios allows us to determine the original magma composition for $\mathrm{MBs}$ discussed in the present paper (Fig. 3). As seen from the diagram, samples of the subalkaline suite range from the rhyodacite/dacite field to the rhyolite field. Several samples fall into the trachyandesite field near the border of rhyolites. The "BB" samples taken at the border of the rhyodacite/dacite and trachyandesite fields coincide with the data on K-bentonites from British Caradoc (Huff et al., 1993).

The presence of the alkalic trachyandesite-trachyte range is worthy of note. The sample of the most peralkalic origin (No. 13, vil49.4) (Fig. 1) comes from the Adavere Stage (Upper Llandovery). A problem arises with establishing the source area of the alkalic magma as there is very little evidence of Caledonian alkalic volcanism in the surrounding areas. In Norway there are registered some restricted occurrences of alkaline igneous rocks (syenites), for example in Vesteralen and Lofoten islands, in Velfjord and Mosjoen in the Bindal and Vefsen districts, and potassium-rich granites in the Stavanger area (Holtedahl, 1960). Mineralogically, the MBs from the trachyte field containing K-feldspar and illitesmectite in different proportions, are all depleted of $\mathrm{Nb}, \mathrm{Y}, \mathrm{Zr}$, and $\mathrm{Ti}$ in comparison with data for unaltered rocks by Winchester and Floyd (1977). 


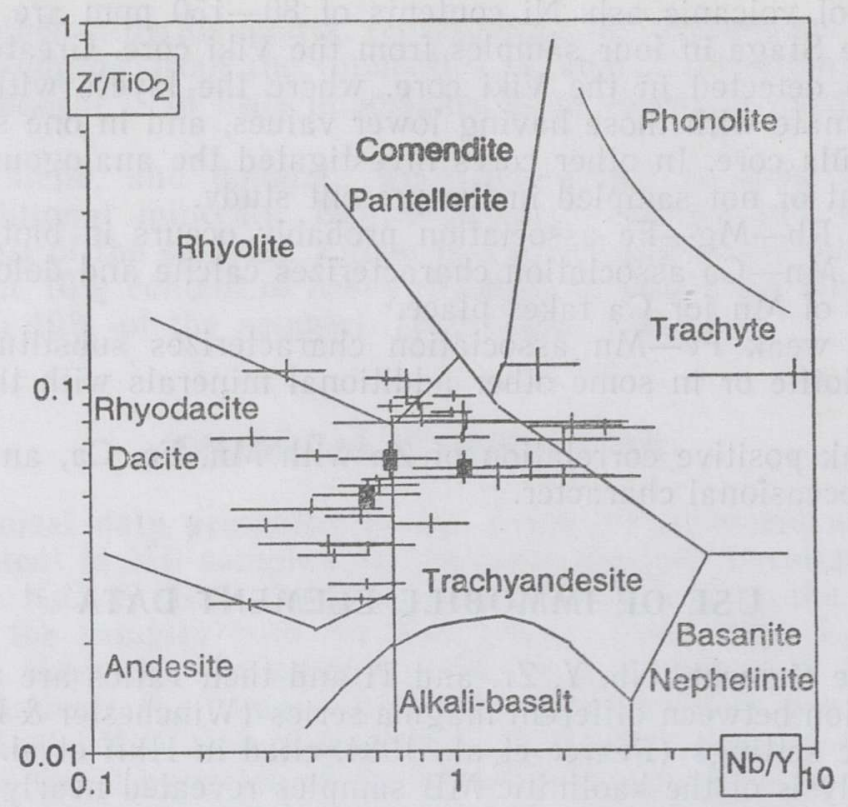

Fig. 3. Samples plotted on the magmatic discrimination diagram of Winchester \& Floyd (1977). Centre of a cross marks the location of the average ratio of a sample given in the Table. The size of the cross shows the analytical variation of the ratio ( \pm 2 standard deviation in numerator and denominator). Filled quadrangles denote three Caradocian "BB" samples. One sample from the trachyte field (No. 13) has the maximum confidence limit of $\mathrm{Nb} / \mathrm{Y}$ ratio up to 53 and is not plotted in whole length.

\section{DIAGENESIS}

The enrichment-depletion phenomenon indicates the changing of the bulk of initial compounds of volcanic substance. Sporadic chertification of the MB-adjacent rocks (Юргенсон, 1966) is an evidence of silica dissolution from the volcanic ash. Chertification of Silurian fossils resulting from the Silurian tephra is described also by Laufeld and Jeppsson (1976).

Kaolinite was probably formed in the simultaneous process of dissolution and precipitation of original volcanic substance in the acidic environment caused by a high content of organic matter. In Ohesaare clays the content of organic matter, determined as loss on ignition at $500^{\circ} \mathrm{C}$, is c. $4 \%$. In Lithuania Lapinskas (Лапинскас, 1965) described the formation of kaolinitic bentonites in Silurian graptolitic argillites from volcanic ash in the acidic environment. La Iglesia Fernandez and Martin Vivaldi (1972) (cited in Snäll, 1978) found that kaolinite formation was favoured by organic agents.

The depletion mentioned above may to some extent be caused by potassium absorption from seawater. The formation of potassium-containing minerals increases the volume of source substance, whereas the percentage of $\mathrm{Nb}, \mathrm{Zr}, \mathrm{Y}$, and other immobile elements stay minor in comparison with their original content in whole rock.

The conditions determining the genesis of either illite-smectite or K-feldspar are still problematic. Since the mineralogical types of rock are distributed irregularly between original magma fields in the Win- 
chester-Floyd diagram, a different volcanic source cannot be the only reason for a varied mineralogical composition. One explanation to the variation of the mineral assemblage might be the combination of diverse facial conditions with the different composition of volcanic source that influences the ratio of illite-smectite and K-feldspar.

\section{CONCLUSION}

The application of the Winchester-Floyd magma differentiation diagram has revealed $\mathrm{MBs}$ of the subalkaline suite ranging from the rhyodacite/dacite field to the rhyolite field, and an alkaline-peralkaline suite ranging from trachyandesite to trachyte source composition. The Ordovician "BB" samples fell within the border area of the rhyodacite/dacite and trachyandesite fields. The alkaline and peralkaline unaltered rocks are characterized by a high $\mathrm{Nb}$ content, but in our case the mean $\mathrm{Nb}$ values are up to five times less. The values of $Y$ have also decreased. So, the only basis for establishing the alkaline-peralkaline source is the characteristic ratio of $\mathrm{Nb}$ and $\mathrm{Y}$. In order to prove the given assumptions, further investigation of alterations in diagenetic processes is needed.

\section{ACKNOWLEDGEMENTS}

The authors thank Erika Jürgenson for kindly providing metabentonite samples and descriptions of thin-sections. We are thankful to Tarmo Kiipli for various discussion during this work. The research was supported by grant No. 949 of the Estonian Science Foundation.

\section{REFERENCES}

Bergström, S. M., Huff, W. D., Kolata, D. R. and Kaljo, D. 1992. Silurian K-bentonites in Iapetus Region: A preliminary event-stratigraphic and tectonomagmatic assessment. - Geol. Fören. Stockh. Förh., 114, 32i-334.

Bergström, S. M., Huff, W. D., Kolata, D. R. \& Bauert, H. 1995. Nomenclature, stratigraphy, chemical fingerprinting and areal distribution of some Middle Ordovician K-bentonites in Baltoscandia. - Geol. Fören. Stockh. Förh., 117, 1-13.

Brusewitz, A. M. 1986. Chemical and physical properties of Paleozoic potassium bentonites from Kinnekulle, Sweden. - Clays and Clay Minerals, 34, 4, 442-454.

Hay, R. L., Lee, M., Kolata, D. R., Matthews, J. C., Morton, J. P. 1988. Episodic potassic diagenesis of Ordovician tuffs in the Mississippi Valley area. - Geology, 16, $743-747$.

Holtedahl, O. (ed.). 1960. Geology of Norway. Norges Geologiske Undersokelse. Oslo. Huff, W. D., Kolata, D. R. 1989. Correlation of K-bentonite beds by chemical fingerprinting using multivariate statistics. - In: Cross, T. A. (ed.). Quantitative Dynamic Stratigraphy. Prentice Hall, New York, 567-577.

Huff, W. D., Merriman, R. J., Morgan, D. J., Roberts, B. 1993. Distribution and tectonic setting of Ordovician K-bentonites in the United Kingdom. - Geol. Mag., 130 (1), 93-100.

Jeppsson, L., Männik, P. 1993. High-resolution correlations between Gotland and Estonia near the base of the Wenlock. - Terra Nova, 5, 348-358.

Jeppsson, L., Viira, V., Männik, P. 1994. Silurian conodont-based correlations between Gotland (Sweden) and Saaremaa (Estonia). - Geol. Mag., 131 (2), 201-218.

Kaljo, D., Kiipli, T., Martma, T. 1996. Carbon isotope event markers through the Wenlock. Pridoli sequence in Ohesaare (Estonia) and Priekule (Latvia). - Paleo., Paleo., Paleo. (in press). 
La Iglesia Fernandez, A., Martin Vivaldi, J. 1972. A contribution to the synthesis of kaolinite. Proc. Intern. Clay Conf., Madrid, 173-184.

Laufeld, S., Jeppsson, L. 1976. Silicification and bentonites in the Silurian of Gotland. Geol. Fören. Stockh. Förh., 98, 31-44.

Nestor, V. 1994. Early Silurian Chitinozoans of Estonia and Latvia. Academia, 4. Estonian Academy Publishers, Tallinn.

Perens, H. 1995. Jaani ja jaagarahu lademe piirikihtidest Saaremaal. - Bull. of Geol. Surv. Est., 5/1, 12-19.

Pearce, J. A., Harris, N. B., Tindle, A. G. 1984. Trace element discrimination diagrams for the tectonic interpretation of granite rocks. - J. Petrol., 25, 956-983.

Rollinson, H. 1993. Using Geochemical Data: Evaluation, Presentation, Interpretation. Longman Scientific \& Technical. New York.

Snäll, S. 1978. Silurian and Ordovician bentonites of Gotland (Sweden). - Stockholm Contributions in Geology, 31, 1-80.

Winchester, J. A., Floyd, P. A. 1977. Geochemical discrimination of different magma series and their differentiation products using immobile elements. - Chemical Geology, 20, 325-343.

Вингисаар П. 1972. О распространении главного слоя метабентонита (d; XXII) в среднем ордовике Балтоскандии. - Изв. АН ЭССР. Хим. Геол., 21, 1, 62-70.

Вингисаар П., Мурникова Т. 1973. Новые данные о минералогии некоторых нижнекарадокских метабентонитов Әстонии. - Изв. АН ЭССР. Хим. Геол., 22, 2, 149-152.

Войткевич Г, В., Закруткин В. В. 1976. Основы геохимии. Высшая школа, Москва.

Кальо Д. Л. (ed.). 1970. Силур Эстонии. Валгус, Таллинн.

Лапинскас П. П. 1965. Метабентониты нижнего силура Литвы. - In: Геология и нефтеносность палеозоя Южной Прибалтики. Гос. геол. ком. СССР, Тр. Ин-та геол., вып. 1. Вильнюс, 49-63.

Мянниль Р. М. 1966. История развития Балтийского бассейна в ордовике. Валгус, Таллинн.

Утсал К., Юргенсон Э. 1971. Минералогия метабентонитов Эстонии. - Изв. АН ЭССР. Хим. Геол., 20, 4, 336-348.

Юргенсон Э. А. 1958. Метабентониты Эстонской ССР. - Тр. Ин-та геол. АН ЭССР, II, 73-85.

Юргенсон Э. А. 1964. Силурийские метабентониты Эстонской ССР. - In: Литология палеозойских отложений Эстонии. Таллинн, $87-100$.

Юргенсон Э. А. 1966. Литология лландоверийских отложений Эстонии. Таллинн.

Юргенсон Ә. А. 1988. Осадконакопление в силуре Прибалтики. Валгус, Таллинн.

\title{
MÕNEDE EESTI METABENTONIITIDE GEOKEEMILINE ISELOOMUSTUS
}

\author{
Enli KIIPLI, Toivo KALLASTE
}

Siluri ja ordoviitsiumi metabentoniitide keemiline ja mineraloogiline analüüs viitab algse vulkaanilise materjali muutustele. Võrreldes eeldatava algmagma koostisega on vähenenud naatriumi ja räni hulk, alumiinium kui mitteliikuv element on jäänud paigale ning mõnel juhul jääkrikastunud. Kaaliumisisalduse suurenemine on seotud selle lisasissekandega, näiteks mereveest. Mikroelementidest on paigale jäänud immobiilsed elemendid, kuid ka nende sisaldus ei vasta algmaterjali omale. Põhjus on samuti jääkrikastumine või suhteline vähenemine, mis kaasneb aine koguhulga suurenemisega, näiteks kaaliumi sidumisel kaaliumpäevakivisse. Eeldades immobiilsete elementide sisalduste suhete säilimist, on võimalik Winchesteri ja Floydi (1977) magma diskriminantdiagrammi abil leida algmagma koostis $\mathrm{Nb} / \mathrm{Y}$ ja $\mathrm{Zr} / \mathrm{TiO}_{2}$ järgi. Uuritud 36 proovi puhul ilmneb, et põhiosa pärineb rüodatsiitsest/datsiitsest ja trahhüandesiitsest, väiksem osa rüoliitsest ja trahhüütsest algmagmast. 


\title{
ГЕОХИМИЧЕСКАЯ ХАРАКТЕРИСТИКА НЕКОТОРЫХ ЭСТОНСКИХ МЕТАБЕНТОНИТОВ
}

\author{
Энли КИЙПЛИ, Тойво КАЛЛАСТЕ
}

Химический рентгенофлюоресцентный анализ элементов в сочетании c рентгенодифракционным минералогическим анализом указывает на изменения в содержании главных и микрокомпонентов в палеозойских метабентонитах по сравнению с первичным вулканическим материалом. Так как корреляционный анализ выявляет несколько ассоциаций элементов, в том числе и иммобильных, то с помощью магматической дискриминационной диаграммы Винчестера и Флойда (Winchester \& Floyd, 1977) можно определить состав первичной магмы по соотношениям $\mathrm{Nb} / \mathrm{Y}$ и $\mathrm{Zr} / \mathrm{TiO}_{2}$. Из 36 изученных метабентонитов Эстонии большая часть имеет риодацитное/дацитное и трахиандезитное происхождение, меньшая часть - риолитное и трахитное. 